\title{
Barriers in Teaching Critical Thinking in Islamic Education
}

\author{
Mohd Isa Hamzah, Nursafra Mohd Zhaffar, Khadijah Abdul Razak \\ Faculty of Education, National University of Malaysia, Bangi, Malaysia \\ Email: isa_hamzah@ukm.edu.my
}

How to cite this paper: Hamzah, M. I. Zhaffar, N. M., \& Razak, K. A. (2018). Barriers in Teaching Critical Thinking in Islamic Education. Creative Education, 9, 2350-2356. https://doi.org/10.4236/ce.2018.914175

Received: August 16, 2018

Accepted: October 28, 2018

Published: October 31, 2018

Copyright $\odot 2018$ by authors and Scientific Research Publishing Inc. This work is licensed under the Creative Commons Attribution International License (CC BY 4.0).

http://creativecommons.org/licenses/by/4.0/

\section{c) (i) Open Access}

\begin{abstract}
Critical thinking helps the discovery of the meaning of a concept about something that being learnt. Accordantly, critical thinking should be infused in teaching Islamic education (IE) for the potential to an effective teaching. Yet, there are some flaws in the teaching of critical thinking in IE among the secondary schools in Malaysia. Therefore, this qualitative study purposely, designed to discover the barriers that being encountered by the Islamic education teachers (IET) in conducting lessons with critical thinking in IE. Data were collected through interviews, lesson observations, and document analysis on six IETs. The finding shows that there are five main themes of barriers that have been faced by the IETs which are: time constraint, limited of teachers' knowledge and skills, students related problems, limited facilities and physical surrounding of the classroom which less supporting the thinking activities.
\end{abstract}

\section{Keywords}

Critical Thinking, Teaching Critical Thinking Barriers, Teaching Critical Thinking, Islamic Education, Islamic Education Teacher

\section{Introduction}

Critical thinking is important to be entrenched in education system, especially in this era where teacher is expected to emphasise on high level thinking aspect in teaching and learning ( $\mathrm{T} \& \mathrm{~L}$ ). This is to prepare the students to be able to face challenges in this 21st Century. Malaysia has launched education transformation in its Malaysia Education Development Plan or known as PPPM which emphasises on high level thinking skill [HOT] explicitly in T \& $\mathrm{L}$ in the classrooms.

Likewise, IE is not left behind in moving together with the government calling to executing HOT based T \& L; which emphasises on one of its elements, critical 
thinking. Critical thinking in IE is designed to assist the student to discover a meaning of a concept critically for self needs or even contribution to the community (Hussien, 2007). Therefore, IE teaching style should be critical in nature and reflective, for its potential in developing students' character and belief for betterment (Hashim. 2007). On top of that, IET functions as not only to produce students with knowledge and skills but also go beyond in developing a good manner among the students (Hashim, 2007; Tamuri, 2007).

Previous researches find that the weakness in critical thinking is distinguished among Secondary school IE in Malaysia. Lesson has been carried out dogmatically; focusing on revelation texts and ritual practises overwhelming the class environment, separated with other subjects and let alone the real life, exam oriented, using more teacher-centred learning, techniques that decrease the development of intellectual level of the students and less cultivating research in teaching (Hashim, 2007; Tamuri, 2016; Muhamad, 2015).

In order to improve the quality of critical thinking teaching, the limitation faced by the teachers should be given attention to. Therefore, this study aims to explore the perceived barriers by IETs in teaching critical thinking in the context of Islamic Education secondary school.

\section{Methodology}

This study used a qualitative approach in the form of case study to gain deeper understanding about the barriers in the teaching critical thinking from IETs' perspectives. In this study, the case refers to a group of IET that have homogenous characteristics. The sample selection is based on purposeful sampling technique (Merriam, 2009). Participants were selected based on criteria identified in advance by the researcher to ensure the information collected is appropriate and adequate. Among the criteria for the selection of study participants is being in the service for more than 5 years, displaying critical teaching in IE and easy to cooperate. Six IETs name have been proposed by State Education Department. Data was collected using semi-structured interviews, observations and documents analysis. The researcher obtained the permission to conduct the study from the Ministry of Education, State Education Department, school principals and IETs involving in this study. The data collection lasted 12 months from September 2015 until September 2016. Data were analysed using ATLAS.ti software version 7.5.15. The content analysis process involves selecting, reducing and giving meaning to the data obtained. Constant comparison method is also used. This comparison was made towards the perceived barriers by participants at different times and also among participants in different locations to identify pattern similarities and differences in data (Strauss \& Corbin, 1998).

\section{Findings}

Overall, the are 5 themes of barriers that affect the execution of imbedding critical thinking by IET in their teaching; time limitation, lack or knowledge mastery and teachers' skill, students related problems, insufficient access of needed facili- 
ties and class physical environment that does not support critical thinking activities.

\subsection{Limitation of Time}

To imbed critical thinking in teaching, a teacher needs to be ready with adequate knowledge and information before the teaching. Yet, the preparation has become the barrier to the teachers since they need to use their free periods at school to complete other tasks like, recording, reporting and fulfilling their responsibilities as class teacher, head of panel, and attending meetings. Thus, the preparation for teaching was neglected. Teachers depend wholly on inherent knowledge to critically discuss a certain topic during lessons.

Apart from that, the process of teaching critical thinking is time consuming. This is due to the fact that the process of understanding the students' point of view by the IETs requires time. There were times when an intense discussion about a particular topic had to be stopped or postponed due to the cessation of a teaching period. Usually, hot topics such as marriage, choice of spouse and the like gave rise to various questions and views from the students. In this instance, time is the constraint.

Teacher $\mathrm{D}$, on the other hand, admits to enjoying encouraging students to think critically through the PI syllabus. However, the need to complete the syllabus within a certain time frame forces the instructor to consider only important topics for the application of critical thinking (U Nur/TB1:175).

\subsection{Limitations of Teachers' Knowledge and Skills}

Teachers are of the opinion that limitation of knowledge regarding certain topics and issues is a stumbling block to critical discussion. The lack of opportunity to discuss in-depth new issues was identified to be the cause of the teachers' knowledge limitations. Without in-depth knowledge, lessons focus only on the basic understanding of the each topic. Meanwhile, conclusions on certain topics were made without thorough considerations. Teachers are also lacking in skills to stimulate students to delve into PI lessons, especially students who are slow learners, come from troubled families and are unmotivated to learn.

\subsection{Students Related Problems}

Due to the large number of students, participants of the study were unable to evaluate the critical thinking level of each individual student during the time frame of a lesson. Therefore, only certain views were selected for extensive discussion, focusing on differing views. For Teacher A, when the number of students in a class exceeds the number of computers or facilities available in an ICT laboratory, searching for information using ICT becomes difficult (Siti/TB3:204). However, the large number of students is not the only problem. Too few students also present a barrier towards the implementation of critical thinking in teaching. Too small a number of students cause insufficient sharing of viewpoints (U Anas/TB6:72). 
The "too lazy to think" attitude of students is also a hindrance to the process of instilling critical thinking. Students who are too lazy to think will ignore complex questions, will have difficulty concentrating for the long periods of time needed to complete a thinking assignment, are more comfortable being spoon-fed and often jump to conclusions without undergoing a thorough thinking process. This phenomenon can be observed during lessons, where a number of students will display uneasiness when asked to answer complex questions.

\subsection{Limited Facilities}

The faculties provided by the school are still inadequate especially those used to search for information, such as computers, slow internet network and insufficient number of LCD and laboratories. On their own initiatives, Teachers A, B and D forked out their own money to buy LCDs to be used for teaching. However, the wiring system in the classes does not support the use of electrical appliances.

Moreover, the lack of resources in the form of courses and training relating to critical thinking and teaching of higher order thinking is not helping the IETs to effectively implement critical thinking. To expedite matters, teachers, on their own initiatives, attend courses organized by external organizations. However, the effectiveness of the course is still an obstacle towards their application in teaching.

\subsection{Physical Surroundings of the Classroom}

The seating arrangements in the classroom are a barrier towards the effective implementation of critical thinking. From the viewpoint of the teachers, the traditional arrangement of students, where chairs and tables are placed in row or individually, causes the students to be less responsive during critical discussions.

Meanwhile, according to Teacher A and Teacher D, an uninformed class becomes an obstruction in the implementation of effective critical thinking. Information, such as short notes of a particular lesson and class information which includes organizational charts, duty rosters, dates of birth and current information regarding school progress, which is displayed on bulletin boards all around the class, is deemed unsupportive of teaching critical thinking. After the text edit has been completed, the paper is ready for the template. Duplicate the template file by using the Save As command, and use the naming convention prescribed by your journal for the name of your paper. In this newly created file, highlight all of the contents and import your prepared text file. You are now ready to style your paper.

\section{Discussions}

The effort to implement critical thinking requires that the IETs create an information-rich class environment. However, the preparation time required to shape such a class is insufficient, due to the fact that most of the teachers' time at school is taken up to fulfill non-essential workload. This finding is supported by 
studies done by Omar (2015) and Hashim (2015) which found that IETs consider their workload to be too heavy. This impedes the IETs' efforts to focus on topics to teach and on planning a strategy to put into practice critical thinking based on the syllabus. This finding is supported by a study done by Snyder \& Snyder (2008) which observed that teachers do experience time constraint problems in preparing and applying critical thinking in teaching. On the other hand, a study by Aliakbari \& Sadeghdaghighi (2013) observed the contrary that time is not an obstructing factor to the use of a teaching strategy based on critical thinking.

From the researcher's point of view, preparedness for critical thinking based teaching should be a life-long ingrained attitude of the teachers, as this is directly linked to the knowledge and critical thinking possessed by the teachers (Zhaffar, Hamzah, Abd Razak, \& Wan Abdullah, 2016). Just as with the students, teachers also build competency gradually, through knowledge and experience (Darling-Hammond, 2008). Thus, time constraint in preparing for critical thinking should not be an obstacle for IETs because they can choose to implement critical thinking starting with well-understood contents. Nonetheless, IETs have to make a commitment towards increasing, from time to time, their knowledge and skills especially those concerning content knowledge. With these efforts, IETs would have knowledge adaptability and flexibility and would be able to easily draw the interests of students and get them to think extensively on topics being taught.

From another aspect, studies have shown that IETs have difficulty completing the education syllabus. With this kind of commitment, not many topics can be discussed at length with the students. For some IETs, emphasis has to be placed on drill exercises and exam topics. The result of this study is in line with the research done by Omar (2015) and Hashim (2015) which highlighted the problem of the IE syllabus. Teachers perceive the syllabus as too much and could not be completed in time.

The researcher is of the opinion that the pressure to finish the syllabus is due to the exam oriented culture ingrained in Malaysia's education system. This is because the researcher observed that teachers, who are not pressured to prepare students so that they may excel in exams, are successful in consistently implementing critical thinking in each phase of teaching. They allow for free time while waiting for ideas from students, discuss each topic exhaustively and let the flow of PdP go according to the needs of the students. In contrast, teachers who are responsible for preparing students for higher order questions in exams seem to be trying to create a pattern or scheme for the students to answer. This is supported by Snyder \& Snyder (2008) and Hashim (2007) who unanimously agree that the exam-oriented culture in the education system causes teachers to focus only on content and not on the learning process of the students. Consequently, the teaching methods of teachers become constrained. In other words, IETs do not apply critical thinking consistently throughout the teaching phase. 
Even though the current exam format contains higher-order questions, if IETS perceive teaching as a process of transferring information only, then, the students' thinking skills cannot be developed. More worryingly, if teachers instruct only for evaluation, then, the information conveyed will become restricted and range-bound as stated by $\mathrm{Pa}$ (1994). Additionally, contents of lessons will not be discussed thoroughly or will be discussed only fleetingly. Consequently, the teaching process won't be able to fulfill the education philosophy's aim to produce balanced and holistic students.

Furthermore, a student's character may also have an effect on the implementation of critical thinking. Students who are unprepared, refuse to offer their opinions, are uninformed, are still unable to master basic matters and are too lazy to think becomes an obstruction to the IETs in implementing critical thinking. This finding correlates with the results from studies done by Mohamad (2008) and Sulaiman (2003) which stated that the problems faced by teachers in implementing critical thinking are caused by the students.

\section{Conclusion}

In conclusion, this study shows that the constraints faced by IETs in implementing teaching of critical thinking are influenced by time, teachers' mastery of knowledge and skills, problems relating to students, facilities available and the physical environment of the class which is unsupportive of critical activities. This study provides an indication for the Ministry of Education to start reassessing the workload of teachers. The heavy workload forces teachers to disregard the core functions of teaching, particularly those concerning teaching preparations needed to stimulate students' critical thinking. Meanwhile, the school has to provide access to as much resources as possible. These include internet access, devices, an ever increasing quantity of quality reading materials in libraries and access to expert sources which can be achieved through active concerted effort with the PIBG. IETs also need to progressively increase their knowledge and create a culture of knowledge. Implementation of critical thinking becomes easy when IETs have a wealth of knowledge. It is hoped that this study will be able to contribute towards the improvement of IE teaching in Malaysia. Headings, or heads, are organizational devices that guide the reader through your paper. There are two types: component heads and text heads.

\section{Conflicts of Interest}

The authors declare no conflicts of interest regarding the publication of this paper.

\section{References}

Aliakbari, M., \& Sadeghdaghighi, A. (2013). Teachers' Perception of the Barriers to Critical Thinking. Procedia-Social and Behavioral Sciences, 70, 1-5.

https://doi.org/10.1016/j.sbspro.2013.01.031 
Darling-Hammond, L. (2008). Teacher Learning that Supports Student Learning. In B. Z. Presseisen (Ed.), Teaching for Intelligence Second Edition. Thousand Oaks, CA: Corwin Press.

Hashim, R. (2007). Rethinking Islamic Education in Facing the Challenges of the Twenty-First Century. American Journal of Islamic Social Sciences, 24, 133-147.

Hashim, R. (2015). Kajian keberkesanan keadah pengajaran, sukatan pelajaran \& pentaksian Pendidikan Islam di sekolah rendah \& menengah kebangsaan: Dapatan keseluruhan \& analisis. Kertas Kerja Muzakarah Pakar Pembentangan Kajian Keberksanan Pendidikan Islam. Kuala Lumpur: Anjuran IKIM, Dewan Besar IKIM.

Hussien, S. (2007). Critical Pedagogy, Islamisation of Knowledge and Muslim Education. Intellectual Discourse, 15, 85-104.

Merriam, S. B. (2009). Qualitative Research: A Guide to Design and Implementation. San Francisco: John Wiley \& Sons.

Mohamad, K. (2008). Amalan penyerapan kemahiran berfikir kritis dalam pengajaran Cerpen KOMSAS Bahasa Melayu. Tesis Dr. Fal., Fakulti Pendidikan, Bandar Baru Bangi: Universiti Kebangsaan Malaysia.

Muhamad, N. A. F. (2015). Pengaruh tahap kepercayaan epistemologi Islam dan tahap konsep kendiri terhadap amalan pengajaran Guru Pendidikan Islam. Tesis Dr. Fal., Fakulti Pendidikan, Bandar Baru Bangi: Universiti Kebangsaan Malaysia.

Omar, N. (2015). Amalan pengajaran Guru Pendidikan Islam berfokuskan kepelbagaian budaya murid: Kajian kes di Negeri Sarawak. Tesis Dr. Fal., Fakulti Pendidikan, Bandar Baru Bangi: Universiti Kebangsaan Malaysia.

Pa, N. A. N. (1994). Penghayatan Wawasan Pembangunan Negara. Kuala Lumpur: Dewan Bahasa dan Pustaka.

Snyder, L. G., \& Snyder, M. J. (2008). Teaching Critical Thinking and Problem Solving Skills. Delta Pi Epsilon Journal, 50, 90-99.

Strauss, A, \& Corbin, J. (1998). Basics of Qualitative Research: Techniques and Procedures for Developing Grounded Theory. Thousand Oaks: Sage Publication, Inc.

Sulaiman, R. (2003). Pelaksanaan pendekatan pengajaran kemahiran berfikir dalam mata pelajaran Sejarah: Satu kajian kes. Tesis Dr. Fal., Fakulti Pendidikan, Bandar Baru Bangi: Universiti Kebangsaan Malaysia.

Tamuri, Ab. H. (2007). Islamic Education Teachers' Perceptions of the Teaching of Akhlāq in Malaysian Secondary Schools. Journal of Moral Education, 36, 371-386. https://doi.org/10.1080/03057240701553347

Tamuri, Ab. H. (2016). Keberkesanan guru dalam pengajaran dan pembelajaran mata pelajaran Pendidikan Islam. Dlm. In M. F. M. Shahran, \& N. H. Saari (pnyt.), Guru Cemerlang Pendidikan Islam: Persediaan dan Cabaran, hlm. (pp. 1-30). Kuala Lumpur: Penerbit IKIM.

Zhaffar, N. M., Hamzah, M. I., Abd Razak, K., \& Wan Abdullah, W. A. A. (2016). Ke arah Guru Pendidikan Islam sebagai pemikir kritis. Sains Humanika, 8, 9-15.

https://doi.org/10.11113/sh.v8n3.739 